\title{
The Combination of Rice Water and BAP Enhances the Multiplication of Grammatophyllum speciosum
}

\author{
DOI: 10.18196/pt.2018.085.92-99
}

\author{
Innaka Ageng Rineksane*, Siti Safitri Nafi'ah and Sukuriyati Susilo Dewi \\ Department of Agrotechnology, Faculty of Agriculture, Universitas Muhammadiyah Yogyakarta, \\ Jl. Brawijaya, Kasihan, Bantul Yogyakarta 55183, Indonesia, Telp: +62 274 387656, Faks: +62 274387646 \\ *Corresponding author, email: rineksane@umy.ac.id
}

\begin{abstract}
Grammatophyllum speciosum is the largest orchid species which lives epiphytically on the trees in the forest. The rate of natural propagation of Grammatophyllum speciosum is very slow. The objective of the research was to determine the effect and the best concentration of rice water and BAP for the multiplication of Grammatophyllum speciosum shoots. The research was a single factor experiment arranged in Completely Randomized Design with several types of multiplication media as treatments. The treatments were MS + 0.5 mg/l BAP, 1/2 MS + 25\% rice water + 0.5 mg/l BAP, 1/2 MS + 50\% rice water + $0.5 \mathrm{mg} / \mathrm{BAP}, 1 / 2 \mathrm{MS}+75 \%$ rice water $+0.5 \mathrm{mg} / \mathrm{BAP}, 1 / 2 \mathrm{MS}+100 \%$ rice water + $0.5 \mathrm{mg} / \mathrm{BAP}, \mathrm{MS}+1 \mathrm{mg} / \mathrm{BAP}, 1 / 2 \mathrm{MS}+25 \%$ rice water + $1 \mathrm{mg} / \mathrm{BAP}, 1 / 2 \mathrm{MS}+50 \%$ rice water + $1 \mathrm{mg} / \mathrm{BAP}, 1 / 2 \mathrm{MS}+75 \%$ rice water $+1 \mathrm{mg} / \mathrm{lBAP}$, and $1 / 2 \mathrm{MS}+100 \%$ rice water $+1 \mathrm{mg} / /$ BAP. Each treatment was replicated ten times. Variables observed in this study were survival rate, browning rate, contamination rate, the percentage of explants sprouting, the increase of shoot height, number of shoots and leaves, the percentage of rooted explants and the number of roots. The data were analyzed by using Analysis of Variance at $\mathbf{a}=5 \%$. The results showed that various concentrations of rice water and BAP were able to multiply the shoots and affect the shoot growth and root length of Grammatophyllum speciosum. The combination of 75\% rice water +1 mg/l BAP on 12 MS medium was the best treatment for Grammatophyllum speciosum multiplication.

Keywords: Rice water, BAP, Grammatophyllum speciosum
\end{abstract}

\section{ABSTRAK}

Grammatophyllum speciosumadalah spesies anggrek terbesar yang hidup secara epifit di pohon-pohon di hutan. Tingkat perbanyakan alami Grammatophyllum speciosum sangat lambat. Tujuan dari penelitian ini adalah untuk mengetahui efek dan konsentrasi air leri dan BAP terbaik untuk perbanyakan tunas Grammatophyllum speciosum. Penelitian ini adalah eksperimen faktor tunggal yang disusun dalam Rancangan Acak Lengkap dengan beberapa jenis media multiplikasi sebagai perlakuan. Perlakuannya adalah MS + 0,5 mg / I BAP, 1/2 MS + 25\% air leri + 0,5 mg / I BAP, 1/2 MS + 50\% air leri + BAP 0,5 mg / I, 1/2 MS +

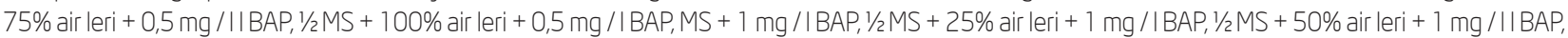
$1 / 2$ MS + 75\% air leri +1 mg / I BAP, dan 1/2 MS + 100\% air leri + 1 mg / B BAP. Setiap perlakuan diulang sepuluh kali. Variabel yang diamati dalam penelitian ini adalah persentase kelangsungan hidup, persentase browning, persentase kontaminasi, persentase tumbuh tunas, pertambahan tinggi tunas, jumlah tunas dan daun, persentase eksplan berakar dan jumlah akar. Data dianalisis dengan menggunakan Analisis Varian pada $a=5 \%$. Hasil penelitian menunjukkan bahwa berbagai konsentrasi air leri dan BAP mampu memperbanyak tunas dan mempengaruhi pertumbuhan tunas dan panjang akar Grammatophyllum speciosum. Kombinasi 75\% air leri + 1 mg / I BAP pada media 1⁄2 MS adalah perlakuan terbaik untuk multiplikasi Grammatophyllum speciosum

Kata Kunci: Air leri, BAP, Grammatophyllum speciosum

\section{INTRODUCTION}

Indonesia has various kinds of ornamental plants. Ornamental plants have good prospects because of increasing demand from both domestic and overseas. One of the beneficial ornamental plants to be developed is orchid. Data from the Data Center and Agricultural Information System (2013) show that 58,656 tons of Indonesian ornamental plants are still dominated by orchids such as aranda, dendrobium, vanda, cattleya, phalaenopsis and grammatophyllum.

Grammatophyllum speciosum is a rare orchid species which is protected by the Government of Indonesia (Government Regulation of the Republic of Indonesia number 7 of 1999). Rimando (2001) stated that Grammatophyllun speciosum is the largest and heaviest orchid among the other types of orchids. Grammatophyllum speciosum is known as the sugarcane orchid and giant orchid due to its size (Destri et al., 2015). Grammatophyllum speciosum also has interesting shapes and colors because there are brown spots that look contrasts to the yellow base color (Ariyanti and Pa'i, 2008). Sopalun et 
al. (2010) stated that the blooming of Grammatophyllum speciosum can remain for up to 2 months. This orchid is also used to prepare an herbal elixir against inflammation. In addition, the orchid has long durability and does not easily wither.

Vegetative propagation of Grammatophyllum speciosum is usually done through splitting or separating orchid clumps which are then planted into the same media as the parent. However, the conventional vegetative propagation is impractical with limited number of seedlings obtained. Similarly, the conventional generative propagation uses seeds in which the seeds are very small without endosperm (food reserves) causing the germination process in the wild nature to be difficult. Therefore, the tissue culture technique is an alternative that can be used for orchid multiplication, especially for Grammatophyllum speciosum.

Sopalun et al. (2010) considered that $15 \mathrm{mg} / \mathrm{l}$ chitosan, a biodegradable polymer, presented the highest relative growth rate (7-fold increase) of Protocorm Like Bodies (PLBs) on liquid medium and 4-fold increase of G. speciosum PLBs on agar medium. Tissue culture technique was also applied to Grammatophyllum speciosum by Samala et al. (2014) stating that the use of half strength MS medium supplemented with $1 \mathrm{mg} / 1$ Benzyl Amino Purine (BAP) in combination with $0.5 \mathrm{mg} / 1 \mathrm{Naph}$ talene Acetic Acid (NAA), 15\% coconut water, $0.2 \%$ activated charcoal presented the highest percentage of protocorm-like body induction and proliferation. However, the use of organic compound supplemented to the medium and shoot bud which is used as explant for Grammatophyllum speciosum multiplication has not been conducted. This research supplemented rice water and BAP on MS medium to induce multiplication of Grammatophyllum speciosum shoot buds.

Rice water is one of the organic materials that can be used to increase the medium nutrient. Rice water is usually used by the community for watering plants around the house. Rice water contains phosphorus for plant cell division. Takliviyah et al. (2014) stated that the addition of white rice water without plant growth regulators treatment into MS medium was the best treatment to produce the number of buds for Grammatophyllum speciosum. Endogenous cytokines on Grammatophyllum speciosum are already able to multiply the buds because they are synthesized in certain parts even though in small amounts. Meanwhile, rice water contains vitamin B1 to form auxin, which if combined with the cytokines can induce buds. Rice water also contains gibberellin that can induce dormant buds.

Shoot multiplication is influenced by plant growth regulator such as cytokines supplemented into the culture medium. Cytokines induce cell division followed by cell differentiation into shoot formation. BAP is one of the cytokines which can be applied to produce shoot multiplication. BAP at the appropriate concentration would interact with rice water and could increase the multiplication of Grammatophyllum speciosum.

The aim of this research was to determine the effect and the best combination of rice washing water and BAP concentrations to the multiplication of Grammatophyllum speciosum shoot.

\section{MATERIALS AND METHOD}

Grammatophyllum speciosum shoots explant were obtained from the orchid breeder in Yogyakarta, Indonesia. Sterile shoots from 12 months old orchids were cultured on MS (Murashige and Skoog) medium supplemented with rice water and BAP in different concentration. The single factor experiment with ten treatments was arranged in Completely Randomized Design. The treatments consisted of MS $+0.5 \mathrm{mg} / 1 \mathrm{BAP}, 1 / 2 \mathrm{MS}+25 \%$ rice water $+0.5 \mathrm{mg} / \mathrm{l} \mathrm{BAP,} 1 / 2 \mathrm{MS}+50 \%$ rice water + $0.5 \mathrm{mg} / 1 \mathrm{BAP}, 1 / 2 \mathrm{MS}+75 \%$ rice water $+0.5 \mathrm{mg} / 1$ 
$\mathrm{BAP}, 1 / 2 \mathrm{MS}+100 \%$ rice water $+0.5 \mathrm{mg} / \mathrm{l} \mathrm{BAP}$, $\mathrm{MS}+1 \mathrm{mg} / \mathrm{l} \mathrm{BAP,} 1 / 2 \mathrm{MS}+25 \%$ rice water +1 $\mathrm{mg} / \mathrm{l} \mathrm{BAP,} 1 / 2 \mathrm{MS}+50 \%$ rice water $+1 \mathrm{mg} / \mathrm{l} \mathrm{BAP}$, $1 / 2 \mathrm{MS}+75 \%$ rice water $+1 \mathrm{mg} / 1 \mathrm{BAP}$, and $1 / 2 \mathrm{MS}$ $+100 \%$ rice water $+1 \mathrm{mg} / \mathrm{l}$ BAP. Each treatment was replicated ten times. Each treatment media was supplemented with $0.5 \mathrm{mg} / 1$ NAA.

\section{Rice Water and Medium Preparation}

Rice water was obtained by washing rice using distilled water. The dose used to prepare rice water was $0.25 \mathrm{~kg} / 1$ for concentration of $25 \%$ rice washing water, $0.50 \mathrm{~kg} / 1$ for $50 \%$ rice water, $0.75 \mathrm{~kg} / 1$ for $75 \%$ rice water and $1 \mathrm{~kg} / \mathrm{l}$ for $100 \%$ rice water. Furthermore, rice water was filtered using a funnel with filter paper placed on the top of the measuring cup or Erlenmeyer. Then rice water was used as materials for preparing the medium. PPM was added and stirred before the medium was poured into the bottles. Plant Preservative Mixture (PPM) is a preservative/biocide broad spectrum highly effective to prevent or reduce the level of microbial contamination of plant tissue culture.

\section{Explant Preparation and Inoculation}

Inoculation of shoots explant was conducted in two stages. The first stage was transferring the shoot explants into MSO medium, thus, the explants were not affected by the plant growth regulators from the previous medium. The second stage was transferring the shoots explant from MSO medium to the treatment medium. Only one shoot explant was inoculated in each bottle. Variables observed in this study were survival rate, browning rate, contamination rate, the percentage of explant sprouting, the increase of shoot height, number of shoots and leaves, the percentage of rooted explants and the number of roots. The data were analyzed by using Analysis of Variance at $\alpha=5 \%$ and further tested using Duncan Multiple Range Test (DMRT) at $\alpha=5 \%$.

\section{RESULTS AND DISCUSSION}

Rice water is organic material containing phosphorus, magnesium and vitamin B1 which is effective when used as additional materials in tissue culture medium for plant propagation. The effect of rice water on Grammatophyllum speciosum growth was determined by several parameters.

\section{The Survival, Browning and Contamination Rate}

The success of in vitro culture is determined by the survival, browning and contamination rate. The higher the survival rate and the lower the percentage of browning and contamination, the success of in vitro culture is increasing. The data

Table 1. The effect of rice water and BAP concentration on the survival, browning and contamination rate of Grammatophyllum speciosum at the $8^{\text {th }}$ week

\begin{tabular}{lccc}
\hline Treatment & Survival rate (\%) & Contamination rate (\%) & Browning rate (\%) \\
\hline MS + 0.5 mg/l BAP & 100 & 0 & 0 \\
$1 / 2$ MS+ $25 \%$ rice water $+0.5 \mathrm{mg} / \mathrm{l} \mathrm{BAP}$ & 90 & 10 & 0 \\
$1 / 2 \mathrm{MS}+50 \%$ rice water $+0.5 \mathrm{mg} / \mathrm{l} \mathrm{BAP}$ & 100 & 0 & 0 \\
$1 / 2 \mathrm{MS}+75 \%$ rice water $+0.5 \mathrm{mg} / \mathrm{l} \mathrm{BAP}$ & 90 & 10 & 0 \\
$1 / 2 \mathrm{MS}+100 \%$ rice water $+0.5 \mathrm{mg} / \mathrm{l} \mathrm{BAP}$ & 90 & 10 & 0 \\
$\mathrm{MS}+1 \mathrm{mg} / \mathrm{l}$ BAP & 90 & 10 & 0 \\
$1 / 2 \mathrm{MS}+25 \%$ rice water $+1 \mathrm{mg} / \mathrm{l} \mathrm{BAP}$ & 80 & 20 & 0 \\
$1 / 2 \mathrm{MS}+50 \%$ rice water $+1 \mathrm{mg} / \mathrm{l} \mathrm{BAP}$ & 90 & 0 & 10 \\
$1 / 2 \mathrm{MS}+75 \%$ rice water $+1 \mathrm{mg} / \mathrm{l} \mathrm{BAP}$ & 100 & 0 & 0 \\
$1 / 2 \mathrm{MS}+100 \%$ rice water $+1 \mathrm{mg} / \mathrm{l} \mathrm{BAP}$ & 90 & 10 & 0 \\
\hline
\end{tabular}


of survival, browning and contamination explant are shown on Table 1.

The survival rate is the ability of the explants to survive and grow in the medium. The viability of explant in tissue culture highly depends on the explant, medium (type and composition), and the amount of plant growth regulator (Miryam et al., 2008). Based on Table 1, the survival rate of Gram matophyllum speciosum is quite high. All treatments show the survival rate of more than 80 percent and the highest contamination rate is 20 percent. This is because of the sterile explants used in this study. In this research, all medium treatment was added by PPM (Plant Preservative Mixture) which can inhibit the growth of pathogens. Therefore, contamination in this culture should not be generated by the medium used. Sharaf and Weathers (2006) stated that PPM is one of the liquid biocides which is included in the isotiazolone group which can inhibit microbes and fungi in in vitro propagation.

Another problem in the technique of tissue culture propagation is browning or blackening on the explants. A cause of browning in tissue culture is injury due to cutbacks in the tissue. The wound spurs the stress and lead to increased activity of Phenylalanine Ammonia Lease (PAL), followed by the activity of the enzyme oxidase (PPO) and cause the browning (Tabiyeh et al,, 2006 in Hutami, 2008). Hutami (2008) also stated that browning in tissue culture occur due to the accumulation of phenolic compounds that released or synthesized tissue undergoes oxidation when the cell is injured. Based on Table 1, the highest percentage of browning is $10 \%$ occuring only on explants cultured on medium $1 / 2 \mathrm{MS}+50 \%$ rice water $+1 \mathrm{mg} / \mathrm{l} \mathrm{BAP}$. The low browning rate in this study was because the explants used were still young, so the explants released only a few phenolic compounds.

The Percentage of Explants Sprouting, the Increase of Shoot Height and the Number of Shoots

The results of the observation of the percentage of explants sprouting, the increase of shoot height and the number of shoots are presented in Table 2 .

\section{The Percentage of Explants Sprouting}

The percentage of explants sprouting is the number of explants capable of growing shoots in each treatment expressed in unit of percent. The higher the percentage of explants sprouting, the higher the explants can regenerate. Based on the observed data (Table 2), the highest percentage of explants sprouting at the $8^{\text {th }}$ week was obtained in the treatment of MS $+1 \mathrm{mg} / \mathrm{l} \mathrm{BAP}$ and MS + 0.5

Table 2. The effect of rice water and BAP concentration on the percentage of explants sprouting, the increase of shoot height and the number of shoots at the $8^{\text {th }}$ week

\begin{tabular}{lccc}
\hline Treatment & $\begin{array}{c}\text { The percentage of } \\
\text { explants prouting }(\%)\end{array}$ & $\begin{array}{c}\text { The increase of shoot } \\
\text { height increase }(\mathrm{cm})\end{array}$ & The number of shoots \\
\hline MS $+0.5 \mathrm{mg} / \mathrm{l} \mathrm{BAP}$ & 70 & $0.98 \mathrm{a}$ & $0.80 \mathrm{a}$ \\
$1 / 2 \mathrm{MS}+25 \%$ rice water $+0.5 \mathrm{mg} / \mathrm{l} \mathrm{BAP}$ & 0 & $0.70 \mathrm{a}$ & $0.00 \mathrm{~b}$ \\
$1 / 2 \mathrm{MS}+50 \%$ rice water $+0.5 \mathrm{mg} / \mathrm{l} \mathrm{BAP}$ & 0 & $1.02 \mathrm{a}$ & $0.00 \mathrm{~b}$ \\
$1 / 2 \mathrm{MS}+75 \%$ rice water $+0.5 \mathrm{mg} / \mathrm{l} \mathrm{BAP}$ & 0 & $0.62 \mathrm{a}$ & $0.00 \mathrm{~b}$ \\
$1 / 2 \mathrm{MS}+100 \%$ rice water $+0.5 \mathrm{mg} / \mathrm{l} \mathrm{BAP}$ & 20 & $0.24 \mathrm{a}$ & $0.20 \mathrm{~b}$ \\
$\mathrm{MS}+1 \mathrm{mg} / \mathrm{l}$ BAP & 60 & $1.03 \mathrm{a}$ & $0.70 \mathrm{a}$ \\
$1 / 2 \mathrm{MS}+25 \%$ rice water $+1 \mathrm{mg} / \mathrm{l} \mathrm{BAP}$ & 20 & $1.26 \mathrm{a}$ & $0.20 \mathrm{~b}$ \\
$1 / 2 \mathrm{MS}+50 \%$ rice water $+1 \mathrm{mg} / \mathrm{l} \mathrm{BAP}$ & 20 & $0.69 \mathrm{a}$ & $0.30 \mathrm{~b}$ \\
$1 / 2 \mathrm{MS}+75 \%$ rice water $+1 \mathrm{mg} / \mathrm{l} \mathrm{BAP}$ & 20 & $0.98 \mathrm{a}$ & $0.20 \mathrm{~b}$ \\
$1 / 2 \mathrm{MS}+100 \%$ rice water $+1 \mathrm{mg} / \mathrm{l} \mathrm{BAP}$ & 0 & $0.54 \mathrm{a}$ & $0.00 \mathrm{~b}$ \\
\hline
\end{tabular}

Note: Means followed by the same letter in the same column, show no significant effect according to DMRT at level $\alpha=5 \%$. 
mg/l BAP (60-70\%). Meanwhile, the treatment of rice water with the addition of 0.5 and $1 \mathrm{mg} / 1$ BAP showed the percentage of explants sprouting of $0-20 \%$. These results indicate that the reduction of macro nutrients in the media of half strength MS causes the ability of explants to sprout to be lower when compared to explants in full strength MS media. Furthermore, the high phosphorus content in rice water is used to stimulate root formation and development. The sulfur content in rice water stimulates the synthesis of thiamin (vitamin B1) which functions to promote root growth and development. Therefore, the treatment of medium given rice water tends to have a lower percentage of sprouted explants both in the addition of $0.5 \mathrm{mg} / 1$ and $1 \mathrm{mg} / 1$ BAP. Wulandari et al. (2011) in Lalla (2018) states that rice washing water contains N 0.015\%, P 16.306\%, K 0.02\%, Ca $2.944 \%, \mathrm{Mg} 14.252 \%$, S $0.027 \%$, Fe $0.0427 \%$ and vitamin B1 0.043\%.

\section{The Increase of Shoots Height}

The increase of shoots height occurs due to the increasing of the number of cells or cell elongation influenced by the nutrients and plant growth regulator in the media. The height of shoots is used as indicator of growth to illustrate the influence of rice water and BAP to the explant height. Based on the data analysis, the concentration of rice water and BAP had no significant effect on the increase of shoot height of Grammatophyllum speciosum (Table 2). However, all media supplemented with $1 \mathrm{mg} / 1 \mathrm{BAP}$ showed higher increase of shoot height compared to the media supplemented with $0.5 \mathrm{mg} / \mathrm{l} \mathrm{BAP}$. This is because BAP is a hormone that stimulates cell division, so that the higher the concentration of BAP used, the more cells are produced. These cells are used to increase shoot height and have not been used to increase the number of shoots. Wattimena (1992) states that growth regulators are generally used in combination and morphogenesis of explants always depends on the interaction between auxin and cytokines. In addition, Lakitan (1996) states that shoot lengthening does not require cytokines in high or low concentrations, because the content of endogenous cytokines is enough. As a result, the addition of exogenous cytokines is no longer influential and can even inhibit growth.

\section{The Number of Shoots}

The increasing number of shoots is an important factor to determine the ability of explants to differentiate cell. BAP is a synthetic cytokine that is most often used because of its ability to induce leaf formation and multiplication of shoots. In addition, BAP is easy to be obtained and the price is relatively cheap (George and Sherrington, 1984). Based on the observations, the treatment of various concentrations of rice water and BAP provided significantly different effect on the number of shoots. Full strength MS Medium without addition of rice water with the addition of BAP 0.5 and $1 \mathrm{mg} / \mathrm{l}$ produced more shoots $(0.7$ and 0.8 shoots) which were more than that of the half strength MS medium with the addition of rice water ( $0-0.3$ buds). This is because rice water contains high amounts of phosphorus so that explant cell division increases. However, cell division occurs in the roots of explants because of the sulfur content in the medium which stimulates the synthesis of thiamin (vitamin B1) which functions to stimulate root growth and development. This is indicated by explants supplemented with rice washing water showing better root growth and development. Reduction of macro nutrients in half strength MS medium also causes low ability of explants to form new shoots.

The number of shoots in the form of decimal numbers was obtained from the number of shoots 
produced by each explant divided by the total number of explants in each treatment. Thus, the number of shoots less than 1 means that there are explants that do not form shoots.

The Number of Leaves, the Percentage of Rooted Explants and the Number of Roots

The effect of rice water and BAP in the medium was also shown by the variables of the number of leaves, the percentage of rooted explants and the number of roots. The results of observations of the three variables are shown in Table 3.

\section{The Number of Leaves}

The increasing number of leaves in orchid plants increases photosynthesis and growth. The number of leaves in each explant was divided by the total number of explants in each treatment. The data in Table 3 show that the addition of different concentration of rice water and BAP had significant effect on the number of leaves per treatment. The highest number of leaves was obtained by $1 / 2 \mathrm{MS}+75 \%$ rice water $+1 \mathrm{mg} / 1$ BAP (2.4 leaves) but not significantly different from that obtained by MS + 0.5 and $1 \mathrm{mg} / 1 \mathrm{BAP}$ (2.2 and 2.1 leaves). This means that rice water can be used to increase the growth of orchids Grammatophyllum speciosum. Meanwhile, the lowest number of leaves was obtained by $1 / 2 \mathrm{MS}$
$+50 \%$ rice washing water $+0.5 \mathrm{mg} / 1 \mathrm{BAP}(0.8$ leaves) and $1 / 2 \mathrm{MS}+100 \%$ rice washing water +0.5 $\mathrm{mg} / 1$ BAP (0.8 leaves). This shows that rice water can increase the growth of orchids Grammatophyllum speciosum when combined with $1 \mathrm{mg} / 1$ BAP. This means that $1 \mathrm{mg} / 1 \mathrm{BAP}$ in the media can encourage meristem cells in the explants to divide and affect other cells to develop to form leaves. In addition, magnesium in the rice water and BAP can be absorbed and it can encourage the formation of leaves. Magnesium is an essential nutrient needed by plants in the formation of chlorophyll and as a cofactor in all enzymes for plant metabolism such as photosynthesis.

The Percentage of Rooted Explants

The percentage of rooted explants is the number of explants rooted in each treatment and expressed in units of percent. The higher the percentage of explants rooted, the more effective absorption of nutrients in explants. The observation results showed that all treatments encouraged rooted explants as much as $40-100 \%$ (Table 3). The explants were rooted in all treatments because of the presence of phosphorus, sulfur and vitamin B1 in the rice water encourage root growth of orchid explants Grammatophyllum speciosum. Phosphorus nutrients are used as constituents of amino acids in

Table 3. The effect of rice water and BAP concentration on the number of leaves, the percentage of rooted explants and the number of roots at the $8^{\text {th }}$ week

\begin{tabular}{|c|c|c|c|}
\hline Treatment & The number of leaves & The percentage of rooted explants (\%) & The number of roots \\
\hline $\mathrm{MS}+0.5 \mathrm{mg} / \mathrm{l} \mathrm{BAP}$ & $2.20 \mathrm{a}$ & 100 & $1.70 \mathrm{a}$ \\
\hline $1 / 2 \mathrm{MS}+25 \%$ rice water $+0.5 \mathrm{mg} / \mathrm{l} \mathrm{BAP}$ & $1.30 \mathrm{ab}$ & 60 & $0.70 \mathrm{bc}$ \\
\hline $1 / 2 \mathrm{MS}+50 \%$ rice water $+0.5 \mathrm{mg} / \mathrm{l} \mathrm{BAP}$ & $0.80 \mathrm{~b}$ & 70 & $0.90 \mathrm{bc}$ \\
\hline $1 / 2 \mathrm{MS}+75 \%$ rice water $+0.5 \mathrm{mg} / \mathrm{l} \mathrm{BAP}$ & $1.20 \mathrm{ab}$ & 60 & $0.80 \mathrm{bc}$ \\
\hline $1 / 2 \mathrm{MS}+100 \%$ rice water $+0.5 \mathrm{mg} / \mathrm{l} \mathrm{BAP}$ & $0.80 \mathrm{~b}$ & 70 & $0.70 \mathrm{bc}$ \\
\hline $\mathrm{MS}+1 \mathrm{mg} / \mathrm{l} \mathrm{BAP}$ & $2.10 \mathrm{a}$ & 80 & $1.30 \mathrm{ab}$ \\
\hline $1 / 2 \mathrm{MS}+25 \%$ rice water $+1 \mathrm{mg} / \mathrm{l}$ BAP & $1.50 \mathrm{ab}$ & 100 & $1.30 \mathrm{ab}$ \\
\hline $1 / 2 \mathrm{MS}+50 \%$ rice water $+1 \mathrm{mg} / \mathrm{l} \mathrm{BAP}$ & $2.00 \mathrm{ab}$ & 40 & $0.50 \mathrm{c}$ \\
\hline $1 / 2 \mathrm{MS}+75 \%$ rice water $+1 \mathrm{mg} / \mathrm{l}$ BAP & $2.40 \mathrm{a}$ & 70 & $0.90 \mathrm{bc}$ \\
\hline $1 / 2 \mathrm{MS}+100 \%$ rice water $+1 \mathrm{mg} / \mathrm{l} \mathrm{BAP}$ & $1.20 \mathrm{ab}$ & 70 & $1.00 \mathrm{bc}$ \\
\hline
\end{tabular}

Note: Means followed by the same letter in the same column, show no significant effect according to DMRT at level $\alpha=5 \%$. 
cell division. Phosphorus also has a role for protein synthesis along with sulfur which also stimulates the synthesis of thiamin (vitamin B1) which functions to stimulate root growth and development.

In addition, the roots formed in all these treatments because NAA was added to all treatment media. NAA concentrations lower than cytokinin concentrations in the medium, encourage root formation in all treatments. George and Sherrington (1984) stated that auxin in low concentrations in the medium can accelerate root formation and affect root elongation.

\section{The Number of Roots}

The number of roots determines the ability of explants to absorb nutrients from the culture medium. The more the number of roots the more absorption of nutrients by explants. The parameters of the number of roots were determined by calculating the number of roots per explant divided by the total number of explants in each treatment. The data in Table 3 show that the treatment of rice water and the concentration of BAP significantly affected the number of roots. This means that the nutrient content in rice water and the combination of BAP and NAA added to the media can encourage root formation. In addition, phosphorus in rice water stimulates the division of root cells and is also supported by sulfur in rice water which promotes the synthesis of thiamin (vitamin B1) to increase root growth and development. Similarly, high magnesium concentrations in the media also function as activators of photosynthesis and respiration enzymes needed for protein synthesis. Zulkarnain (2009) added that high nitrogen concentrations in MS media encourage the formation and elongation of roots, this is because increased leaf area can encourage root growth.
The highest number of roots was obtained by treatment MS+ $0.5 \mathrm{mg} / 1 \mathrm{BAP}$ (1.7 roots) and not significantly different from that obtained by MS + $1 \mathrm{mg} / \mathrm{l} \mathrm{BAP}$ (1.3 roots) and $1 / 2 \mathrm{MS}+25 \%$ rice water $+1 \mathrm{mg} / \mathrm{l} \mathrm{BAP}$ (1.3 roots). Although the number of roots in the treatment of rice water was less than the full strength MS treatment, the use of rice water produced longer roots. This is because phosphorus in rice washing water is used for cell division and elongation of explant roots.

\section{CONCLUSION}

Rice water and various concentrations of BAP can multiply the shoots and affect the root growth and length of Grammatophyllum speciosum. The addition of $75 \%$ rice water $+1 \mathrm{mg} / \mathrm{l}$ BAP on $1 / 2 \mathrm{MS}$ medium was the best treatment for multiplication of Grammatophyllum speciosum.

\section{REFERENCES}

Ariyanti, E.E. and Pa'i. 2008. Orchids Inventory in Sintang Regency West Kalimantan. Biodiversitas 9(1):21-24. DOI: 10.13507/ biodiv/d090106.

Data Center and Agricultural Information System. 2013. Sector Macro Indicator. Republic of Indonesian Ministry of Agriculture. Bulletin of the Agricultural 8 (3):

Destri, A. F, Harto and Kusnadi. 2015. Survey on Orchid Diversity in Bangka Tengah and Belitung Districts, the Province of Bangka Belitung Island. National Seminar Proceeding of Biodiversity Society Indonesia 1 (3): 509-514. DOI:10.13057/ psnmbi/m010322

George, E.F. dan P. D. Sherrington. 1984. Plant Propagation by Tissue Culture. Handbook and Directory of Comercial Laboratories. Exegetics Ltd., Everslay. Basingtoke. England. 709p

Government Regulations. 1999. Protected Types of Plants and Animals. Attachment of Government Regulation of the Republic of Indonesia Number 7. January 27, 1999.

Hutami, S. 2008. Problems with Browning on Tissue Cultures. Jurnal Agro Biogen 4 (2):83-88

Lakitan, B. 1996. Physiology of Plant Growth and Development. PT Raja Grafindo Persada. Jakarta. 187p

Lalla, M. 2018. Potential of Rice Washing Water as Organic Fertilizer on Apium graveolens L. Jurnal Agropolitan, 5(1):38-43

Miryam, A, I. Suliansyah, dan A. Djamaran. 2008. Multiplication of Citrus nobilis $L$. in Several NAA and BAP Concentrations in In Vitro WPM Medium. Jerami.1(2): 1-8. 
Rimando, T. J. 2001. Ornamental Horticulture a Little Giant in The Tropics. SEAMEO SEARCA and UPLB. Philipines. 99p

Samala, S., S. Te-chato, S. Yenchon and K. Thammasiri. 2014. Protocorm-Like Body Proliferation of Grammatophyllum speciosum through Asymbiotic Seed Germination. Science Asia 40: 379-383. DOI. 10.2306/scienceasia1513-1874.2014.40.379.

Sopalun, K., K. Thammasiri and K. Ishikawa. 2010. Effects of Chitosan as The Growth Stimulator for Grammatophyllum speciosum in Vitro Culture. World Academy of Science, Engineering and Technology International Journal Biotechnology and Bioengineering 4(11): 828-830

Sharaf, E. M.A. dan Weathers, P. 2006. Movement and Containment of Microbial Contamination in The Nutrient Mist Bioreactor. In vitro Cell \& Developmental Biology-Plant 42(6): 553-557

Takliviyah, L., A.S. Pambudi dan A.D. Ariananta. 2013. The Effectiveness of Numeri "Natural Nutrition of Rice Washing Water" as a Substitute of Synthetic Nutrition in Grammatophyllum speciosum Orchid In Vitro. Fakultas Pertanian Universitas Muhammadiyah Yogyakarta. Yogyakarta.

Wattimena, G.A. 1992. Plant Growth Regulator. PAU Bioteknologi. IPB. Bogor.

Zulkarnain. 2009. Plant Tissue Culture. Bumi Aksara. Jakarta. 249p 